\title{
CARCINOMA DO COLO EM ÚTERO PROLAPSADO
}

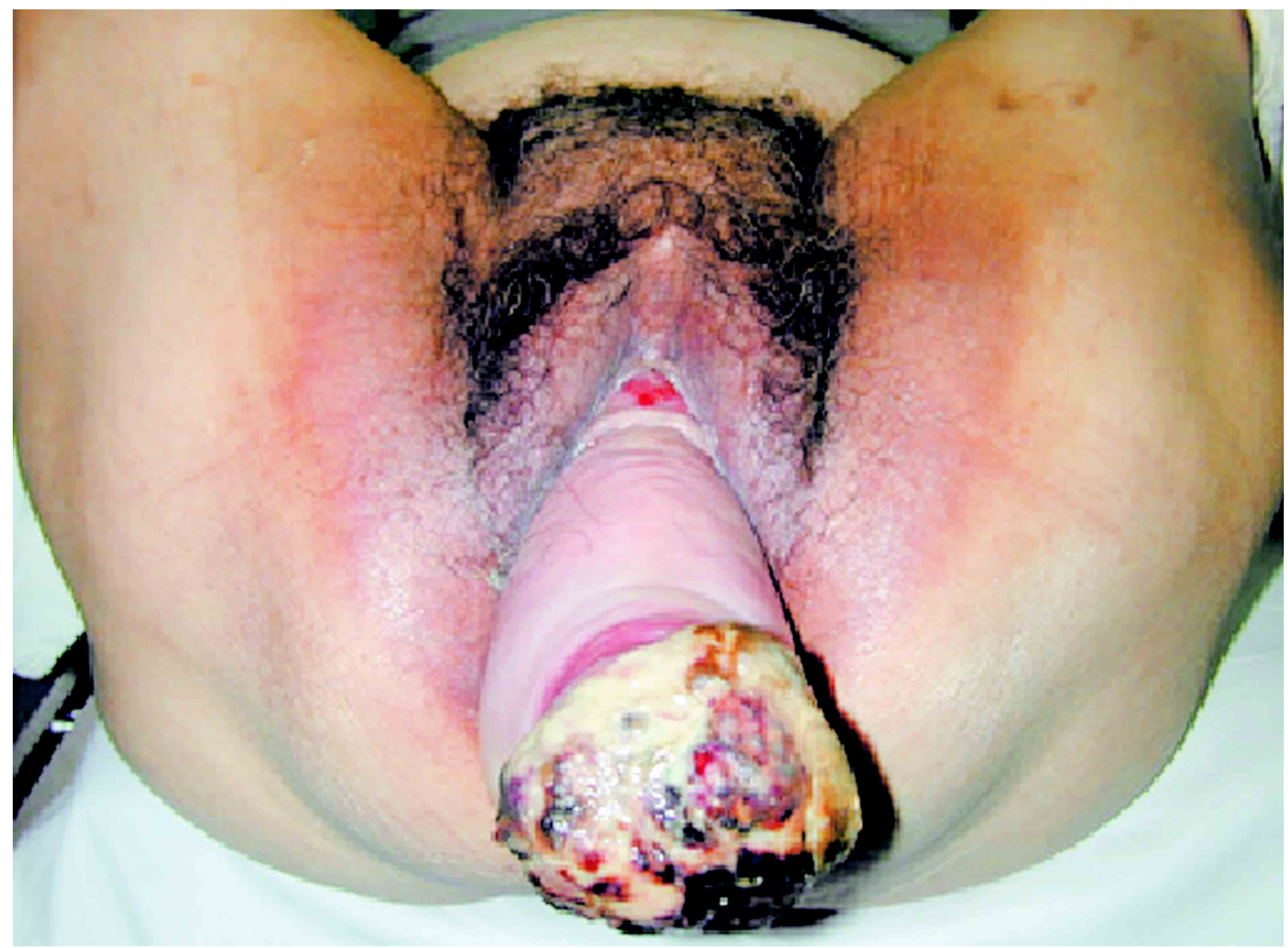

Paciente de $7 \mathrm{I}$ anos de idade, com prolapso uterino de terceiro grau e carcinoma epidermóide invasivo do colo, deu entrada no Serviço de Emergência com quadro de hemorragia genital severa. Foi feito transfusão sangǘnea, tamponamento com hipossulfito de sódio a $10 \%$, antibioticoterapia e radioterapia com finalidade hemostática em duas sessões diárias de 500 cGy. No terceiro dia, foi realizado histerectomia e salpingo-ooforectomia bilateral por via vaginal. Completou o tratamento com radioterapia pélvica nas doses habituais.

Jesus Paula Carvalho

Giovanni Mastrantonio Di favero

Setor de Oncologia Genital Feminina - Clínica Ginecologica do Hospital das Clínicas da Faculdade de Medicina da Universidade de São Paulo, S. Paulo, SP. 